\title{
Pengendalian Asas Kebebasan Berkontrak Dalam Sistem Pre Project Selling
}

\author{
Irwan Gomulja \\ Fakultas Hukum Magister Kenotariatan Universitas Narotama \\ igohoki@gmail.com \\ Habib Adjie \\ Fakultas Hukum Magister Kenotariatan Universitas Narotama \\ habibadjie8@gmail.com
}

DOI: $10.23917 /$ laj.v5i1.10395

Submission
Track:
Received:
27 Februari 2020

ABSTRAK

Pre Project Selling merupakan penjualan sebelum proyek dibangun dimana property yang dijual tersebut baru berupa gambar atau konsep. Konsep pemasaran semacam ini menjadi tren pada era modern terutama bagi para pengembang (Developer). Asas Kebebasan Berkontrak dalam perjanjian merupakan suatu landasan yang wajib

Final Revision:

17 Maret 2020

Available online:

28 April 2020

Corresponding Author:

Irwan Gomulja igohoki@gmail.com dimiliki dalam hal perjanjian dalam transaksi pre project selling. Dalam kontrak konsumen yang dilakukan dalam bentuk tertulis standar yang dipersiapkan sebelumnya oleh developer. Penelitian ini menggunakan metode penelitian yuridis normative dengan pendekatan undang-undang. Penelitian ini merupakan penyelesaian atas akibat penggunaan sistem pre project selling yang belum mempunyai payung hukum. Sistem pre project selling saat ini memiliki kecenderungan menguntungkan developer/pengembang dan memiliki kecenderungan lebih tinggi untuk merugikan konsumen Mengingat asas hukum di Indonesia menggunakan asas legalitas, apabila belum ada undangundang yang mengaturnya terlebih dahulu maka tidak ada hukuman atas perbuatan yang dilakukan tersebut. Dengan demikian sudah sepatutnya peraturan mengenai pre project selling segera disahkan dan/atau dibuat untuk memberikan payung hukum bagi para konsumenTujuan penelitian ini supaya adanya pengendalian asas kebebasan berkontrak yang diterapkan dalam sistem pre project selling, sehingga konsumen tidak dirugikan untuk pembelian property yang menggunakan sistem pre project selling. Belum adanya aturan mengenai Pre Project Selling dalam Peraturan Perundang-undangan yang berlaku membuat pengendalian perlindungan konsumen tidak maksimal. Perlunya Pemerintah untuk membuat regulasi akan hal ini.

Keywords: Asas kebebasan Berkontrak, Pre Project Selling, Perjanjian 


\begin{abstract}
Pre Project Selling is a sale before building a project where the property to be sold is just a picture or concept. This concept of marketing has become a trend in the modern era, especially for developers. The principle of freedom of contract in an agreement is a must-have foundation in the case of a deal in a pre-project selling transaction. In consumer contracts made in written form, standards are prepared by the developer. This study uses a normative juridical research method with a statutory approach. This research is a solution to the consequences of using the pre-project selling system that does not yet have a legal umbrella. The current pre-project selling system tends to benefit developers and has a higher tendency to harm consumers. Considering the principle of law in Indonesia uses the principle of legality, if no law regulates it first, then there is no penalty for the act committed. Thus it fits for regulations regarding pre-project selling to be immediately passed and/or made to provide a legal umbrella for consumers. The purpose of this study is that the control of the principle offreedom of contract is applied in the pre-project selling system so that consumers are not disadvantaged for the purchase of property that uses the pre-project selling system. The absence of rules regarding Pre Project Selling in the applicable laws and regulations makes controlling consumer protection not optimal. The Government needs to make regulations on this matter.
\end{abstract}

Keywords: Freedom of Contracting Principle, Pre Project Selling, Agreement

\title{
PENDAHULUAN
}

Kebebasan Berkontrak merupakan suatu asas yang dapat memungkinkan para pihak yang membuat Perjanjian yang sesuai dengan kehendaknya. Dukungan dari asas ini yang didasarkan oleh dinamika ekonomi pasar bebas dan individualisme dalam masyarakat. Pemikiran kebebasan berkontrak mempunyai tujuan untuk mendatangkan kesejahteraan seoptimal mungkin (Ridwan \& Rusdiana, 2018).

Temuan dari asas kebebasan berkontrak dalam pasal 1338 ayat (1) KUHPerdata yang disebutkan dalam "bagi mereka yang membuat undang-undang yang berlaku, semua perjanjian yang dibuat secara sah" Pasal yang mempunyai kaitan dengan penjabaran dari asas kebebasan berkontrak, dari kata "semua" yang menyimpulkan kebebasan untuk: 1) Suatu perjanjian atau tidak membuat perjanjian dibuat bebas. 2) Perjanjian dengan siapapun yang dibuat bebas. 3) Bentuk Perjanjian yang diatur bebas. 4) Isi dan syarat perjanjian yang dibuat diatur bebas. 5) 
Pilihan hukum diadakan bebas. Kebebasan berkontrak yang mencakup kebebasan untuk memilih pihak dengan siapa perjanjian yang akan dibuat (Hernoko, 2016).

Salah satu cakupan dari asas kebebasan berkontrak adalah kebebasan untuk memilih pihak dengan siapa seseorang ingin membuat perjanjian.1 Cakupan tersebut bermakna seseorang dapat memilih atau menolak untuk membuat perjanjian dengan orang lain berdasarkan pertimbangan subjektif atau objektif dirinya. Pertimbangan yang digunakan sangat erat kaitannya dengan tujuan perjanjian yang akan dibuat, misal dalam perjanjian kerja pertimbangan dalam memilih pekerja adalah kualifikasi dan kemampuan seseorang untuk mengisi posisi tertentu (Sjahdini, 2009).

Kebebasan berkontrak yang menyimpulkan ketentuan pasal 1338 ayat (1) KUH Perdata, yang menyatakan bahwa semua kontrak (perjanjian) yang dibuat secara sah berlaku sebagai undang-undang bagi mereka yang membuatnya. Menurut Hukum Perdata yang berlaku di Indonesia, Kebebasan berkontrak bersumber dari kebebasan individu sehingga yang merupakan titik tolaknya adalah kepentingan individu pula. Dengan demikian dapat dipahami bahwa kebebasan individu memberikan kepadanya kebebasan untuk berkontrak (Mardan, 2015). Asas konsensualisme yang berlaku menurut hukum perjianjian Indonesia memantapkan adanya asas kebebasan berkontrak. Salah satu pihak yang membuat perjanjian tanpa sepakat maka perjanjian yang dibuat dapat dibatalkan. Orang tidak ada paksaan untuk memberikan sepakatnya. Asas kespakatan atau yang disebut dengan contradiction interminis. Namun jika terjadi paksaan karena tidak adanya kesepakatan itu merupakan pilihan. Jadi sikap tolakan yang berakibat pada perjanjian atau kesepakatan yang tidak terlaksana.

Dalam ketentuan hukum perjanjian di Indonesia, barang siapa seseorang mendapatkan kebebasan dalam hal memilih membuat kesepakatn sesuai dengan siapa yang dia mau. Di dalam perundang-udnangan hanya mengatur tentang ketentuan cakap atau tidaknya sesorangn dalam membuat perjanjian. Dimana disebutkan dalam Undang-undang pada pasal 1330 KUHPerdata. Kemudian pada pasal 1331 KUHPerdata ditambahkan juga tentang ketentuan perjanjian, apabila sudah dilakukan perjanjian dengan orang yang tidak cakap hukum maka perjanjian tersebut masih sah di mata hukum kecuali para pihak mempermasalahkannya (Mardan, 2015). Dalam ketentuan KUHPerdata, asas kebebasan berkontrak tidak secara penuh memiliki kebebesan yang mutlak namun tetap ada batasan ketentuannya. 
Dalam pasal 1320 ayat 1 , bahwasanya perjanjian atau kontrak dikatakan belum sah apabila tidak ada kesepakatan para pihak. Jadi ketentuan tersebut dibatasi oleh sepakat atau tidaknya kedua belah pihak. Kemudian pada pasal 1320 ayat 2 kebebasan seseorang dalam hal membuat suatu perjanjian dibatasi terkait kecapakannya di muka hukum. Pada pasal 1330 orang yang belum dewasa dan orag yang mendapatkan pengampuhan tidak diperkenankan untuk melakukan perjnajian dalam bentuk apapun (Mardan, 2015).

Pada pasal 1320 ayat 3 terkait objek perjanjian harus ditentukan terlebih dahulu. Prestasi dalam perjanjian harus dapat dipenuhi oleh kedua pihak Jadi apa yang diperjanjiakn harus jelas. Alasan kenapa suatu prestasi dalam perjanjian harus ditentukan yakni ketika prestasi tersebut tidak dilaksanakan oelh salah satu pihak maka perjanjia tersebut batal demi hukum atau dianggap tidak ada perjanjia yang pernah terjadi.

Pada pasal 1320 jo Pasal 1337 semua pihak tidak dapat bebas membuat perjanjian yang dilarang oleh undang-undang. Dalam ketentuan undang-undang terkait sebab yang halal itu apabila tidak dilarang atau bertentangan dengan norma ketentuan yang ada. Akibat hukumnya apabila kesepakatan tersebut tetap dilakukan maka perjanjian tersebut akan batal demi hokum (Hosiana, 2019).

Sedangkan mengenai obyek perjanjain yang diatur dalam pasal 1332 disebutkan bahwa hanya barang yang dapat diperdagangkan atau barang yang memiliki nilai ekonomis saja yang dijadikan obyek perjanjian(Mardan, 2015). Terkait kebebasan berkontrak juga disebutkan pada pasal 1338 ayat 3 yakni dalam mengadakan suatu perjanjian harus memiliki iktikad baik terhadap perjanjian tersebut. Maka dari itu para pihak dapat memiliki kebebasan yang tidak terbatas terkait dengan klausul-klausulnya namun tetap diwajibkan ada unsure iktikad yang baik dalam penyusunannya. Suatu perjanjian yang pada dasarnya memiliki iktikad yang tidak baik maka dapat dibatalkan demi hukum.

Menurut Prof. Asiskin Kusuma Atmaja memberikan tanggapan terkait pembatasan pada asas kebebasan berkontrak, Hakim memiliki kewenangan untuk dapat memeriksa dan meneliti secara mendalam terkait isi kontrak di suatu persidangan apabila isi kontrak tersebut bertentangan dengan kondisi norma yang berlaku dimasyarakat. Jadi kesimpulannya ketentuan pasal 1338 kebebasan berkontrak bukanlah asas yang serta merta tidak dapat diganggu gugat, namun selama Hakim merasa perlu untuk memeriksa kontrak tersebut di muka persidangan hal ini juga menjadi penyebab salah satu pihak yang tidak leluasa menjabarkan kehendak yang diinginkannya (Mardan, 2015). 
Secara umum kebebasan berkontrak dapat menimbulkan ketidakadilan dikarenakan posisi tawar para pihak yang tidak seimbang. Dalam perkembangannya kebebasan berkontrak dibatasi melalui peraturan perundangundangan, ketertiban umum, dan kesusilaan. Untuk membatasi kebebasan para pemilik tempat tinggal dalam melakukan diskriminasi dalam pemilihan pihak, Kongres di Amerika Serikat membuat undang-undang yang melarang diskriminasi dalam sewa tempat tinggal dengan dasar ras, warna, agama, jenis kelamin, dan bangsa dalam Fair Housing Act (Rabin, 1984).

Seperti salah satu contoh pada kesepakatan penjualan Rumah Susun pada pasal 42 dan pasal 43 yakni terkait aturannya pemasaran sebuah rumah susun dapat dilakukan kemudian diikat menjadi sebuah PPJB. Kemudian keentuan pasal 43, pelaksanaan PPJB haruslah bangunan berdiri minimal 20\%. Hal ini sebenarnya mengundang kerancuan pada Undangundang Rumah Susun dimana agar pembeli berhati-hati.

Pada fakta dilapangan sering kali pemilik atau pemrakarsa proyek perumahan belum mampu memnuhi persyaratan tersebut. Oleh karena itu dalam penjualan rumah susun dengan system Pre Project Selling harus diberikan surat pesanan terlebih dahulu dikarenakan para konsumen sudah melakukan pembayaran uang muka. Namun jika dalam perjalanannya tidak memenuhi ketentuan yang disyaratkan undang-undang maka pemrakarsa proyek perumahan memiliki inisiatif untuk melakukan perjanjian pemsesanan terhadap konsumen.

Pre Project Selling adalah suatu system pemasaran yang dilakukan ketika pembangunan belum sama sekali dilakukan. Alasan dilakukannya system seperti ini yakni karena pembangunan gedung-gedung bertingkat muali dari hunian, perkantoran, hingga pusat rekreasi seperti mall di wilayah Indonesia yang berkembang sangat pesat sehingga berdampak pada persaingan bisnis pemasaran property dalam menggaet calon konsumennya (Purbandari, 2013).

Dari proses pembayarannyapun juga memiliki skema yang di mudahkan oleh penjual, sehingga promosi ke calon konsumen semakin maksimal. Perjanjian ini merupakan perjanjian yang bersifat pendahuluan atau pengantar. Nantinya hasil kesepakatan kedua belah pihak tetap tercatat dalam Perjanjian Jual Beli atau PJB. Dalam ketentuan pasal 1233 KUHPerdata setiap perikatan yang dibentuk baik karena persetujuan kedua belah pihak, baik juga menurut undangundang selanjutnya dibuat AJB (Akta Jual Beli) dihadapan PPAT.

Dalam hal perjanjian pendahuluan tidak diatur dalam KUHPerdata, namun tertuang pada pasal 42 ayat 1 Undang-undang no 1 tahun 2011 Tentang Perumahan dan Kawasan 
Pemukiman yakni Rumah Deret, rumah tunggal dan/atau rumah susun yang masih dalam tahap proses pembangunan dapat dipasarkan melalui system perjanjian pendahuluan jual beli sesuai dengan ketentuan peraturan perundang-undangan yang berlaku. Pada dasarnya praktek terkait perjanjian tersebut dituangkan dalam bentuk kontrak. Pembentukan kontrak didasarkan pada kepentingan kedua belah pihak yang aka mengikatkan diri pada kontrak tersebut. Proses pembentukan pasal per pasal dalam kontrak dibutuhkan komunikasi dan negosiasi yang harusnya tidak merugikan pihak manapun (Nizam, 2017).

Suatu perjanjian jual beli harusnya memiliki kewajiban yang harus dipenuhi oleh setiap pihak sebelum nantinya pelaksanaan janji dalam klausul kontrak bisa dicapai. Perjanjian pendahuluan dapat difungsikan untuk meminimalisir adanya sengketa dalam jual beli terkait pembayaran angsuran. Yang terpenting adalah prinsipnya berisi klausul yang berisi tentang kewajiban dan hak para pihak. (Christie, 2012)

Dalam pengertian perjanjian pendahuluan menurut Munir Fuady ialah perjanjian yang sesuai dengan asas kebebasan berkontrak. Pasal 1338 ayat 1 kedua belah pihak memiliki kebebasan melakukan perjanjian baik dari segi isi atau perselisihan, sepanjang sesuai dengan ketentuan Undang-undang dan tidak bertentangan dengan norma yang berlaku di msyarakat serta adanya iktikad baik antara pihak 1 dengan yang lain (Fuady, 2001)

Dalam ketentuan pasal 1457 KUHPerdata yakni apabila suatu perjanjian sudah dilakukan yang kemudian ada kewajiban salah satu pihak untuk menyerahkan suatu kebendaan, dan kemudian pihak yang lain diwajibkan melakukan pembayaran. Pengertian perjnajian jual beli pada pasal tersebut merupakan perjanjian obligatoir dan disebut juga perjanjian kebendaan yang pengertiannya dimana perjanjian yang dilakukan kemudian obyek kebendaan tersebut beralih tangan kepada pemilik baru yang lain. Penyerahan kebendaaan atau beralihnya kebendaan tersebut setelah dilakukan pembayaran yang kemudian pemilik baru dapat merubah nama kepemilikan benda tersebut (Satrio, 1995)

Adanya suatu iktikad baik dalam perjanjian jual beli nantinya akan diberikan perlindungan hukum oleh Negara. Kemudian dalam pasal 1458 menyebutkan bahwa jual beli dianggap telah terjadi apabila terjadi kesepakatan terkait barang dan harganya.

Namun dalam prakteknya sudah banyak praktek perjanjian yang sudah dituangkan dalam klausul formal yang berbentuk formulir yang kemudian disebut perjanjian baku. Dalam praktek jual beli yang lebih sering digunakan adalah perjanjian yang bersifat baku. Kontrak baku seperti ini sudah digunakan oleh pelaku bisnis dikarenakan lebih praktis. Kontrak baku umumnya 
dibuat oleh salah satu pihak bahkan lebih praktis lagi sudah berbentuk formulir. Ketika kontrak atau formulir tersebut maka pihak pengusaha lebih kearah memberikan bantuan untuk mengisi data yang ada pada formulir yang belum diisi. Kelemahan dari kontrak baku seperti ini yakni pihak pembeli tidak dapat lagi melakukan negosiasi dengan pihak penjual sehingga terkesan berat sebelah (Fuady, 2001). Tidak adanya kesempatan untuk dapat melakukan negosiasi terkait klausul yang baku tersebut merupakan kerugian yang sangat besar. Dengan demikian tujuan penelitian ini supaya penerapan asas kebebasan berkontrak untuk sistem pre prject selling tidak merugikan bagi konsumen. Dengan adanya penelitian ini diharapkan para pemangku kepentingan dapat lebih mengedepankan keseimbangan hukum diantara para pihak. Sehingga konsumen dalam membeli property dengan sistem pre project selling tidak dirugikan secara serta merta oleh pengembang/developer. Mengingat asas hukum di Indonesia menggunakan asas legalitas, apabila belum ada undang-undang yang mengaturnya terlebih dahulu maka tidak ada hukuman atas perbuatan yang dilakukan tersebut. Dengan demikian sudah sepatutnya peraturan mengenai pre project selling segera disahkan dan/atau dibuat untuk memberikan payung hukum bagi para konsumen. Maka, rumusan masalah dalam penelitian ini adalah, bagaimana pengendalian asas kebebasan berkontrak dalam sistem pre project selling?

\section{METODE PENELITIAN}

Dalam penelitian ini menggunakan metode penelitian yuridis normative dengan pendekatan undang-undang. Pengertian yuridis normative merupakan penelitian yang ditinjau dari sudut pandang internal yang menjadikan norma hukum sebagai obyek penelitian. (Diantha, 2016). Sumber data dalam penelitian ini menggunakan data yang ditelaah secara bahan hukum primer dan sekunder. Bahan hukum primer merupakan peraturan perundang-undangan sedangkan untuk bahan hukum sekunder diperoleh dari karya ilmiah atau doktrin tokoh hukum dan literature. Teknik pengumpulan data dilakukan dengan mengumpulkan peraturan perundang-undangan mengenai asas kebebasan berkontrak dan sistem pre project selling. Teknik pengumpulan data ini menggunakan teknik pengumpulan data studi pustaka. Jadi data dalam penelitian ini diambil dari peraturan perundnag-undangan, buku, jurnal, pendapat hukum dan sebagainya.

Kemudian data tersebut ditelaah dan dikaitkan dengan permasalahan yang akan diangkat yakni pengaturan hukum terhadap pengendalian asas kebebasan berkontrak dalam 
system pre project selling. Teknik analisis data dilakukan untuk memeriksa kelengkapan data yang telah dikumpulkan. Selanjutnya dilakukan pemeriksaan kualitas data untuk menentukan berapa data yang missing dan/atau diperlukan penambahan. Analisis data pada metode ini menggunakan analisis data kualitatif dengan penentuan konsep atas penelitian yang akan dilakukan.

\section{HASIL DAN PEMBAHASAN}

Pemasaran rumah susun dengan model informasi saja dimana pada faktanya unit rumah tersebut belum terbangun sama sekali, merupakan cara yang digunakan oleh kebanyakan pengembang property sekarang ini. Apalagi yang dipasarkan oleh mereka hanyanberbentuk denah dan rencana lokasi saja, apalagi dalam hal lealitasnya pun juga masih belum terpenuhi. Strategi seperti ini disebut juga system pemasaran Pre Project Selling (Simamora, 1996)

Strategi ini dianggap oleh pengemang property yang paling masuk akal dan sangat menguntungkan, dikarenakan nantinya uang muka yang sudah dibayarkan oleh konsumen akan dijadikan modal untuk mendirikan bangunan. Dalam hal ini juga telah terjadi kesepakatan dan saling percaya antara pengembang dengan konsumen yang nantinya akan berkomitmen memberkan kewajibannya untuk melunasi sisa pembayaran ketika unit rumah tersebut telah berdiri sesuai dengan perjanjian(Purbandari, 2013).

Konsep strategi ini menjadikan pengembang memiliki perputaran keuangan yang sangat aman. Beban modal untuk pengerjaan konstruksi sangat dibantu dari dana uang muka yang diberkan oleh konsumen, dimana konstruksi tersebut biasanya minimal 20-30\%.

Nantinya system seperti ini menjadikan posisi pengusaha property menjadi semakin aman, karena tidak adanya spekulasi yang nantinya merugikan atau diingkari oleh konsumen. Kesepakatan sudah tercapai dan memiliki jadwal pembayaran tersendiri. Beberapa dasar daripada konsep pembelian dengan system pre project selling yakni:

a. Konsumen harus cermat dalam menanyakan terlebih dahulu legalitasnya;

b. Jika nantinya unit rumah tersebut akan dimiliki dan dihuni sendiri maka alangkah baiknya memilih lokasi unit yang strategis sesuai kebutuhan;

c. Fakta di lapangan unit rumah yang dipasarkan dengan system Pre Project Selling lebih murah dengan unit rumah yang sudah jadi atau yang sudah berdiri;

d. Dipastikan bahwasanya sebelum melakukan pembayaran uang muka, konsumen diwajibkan sudah memiliki kredit kepemilikan rmah yag sudah disetujui oleh pihak Bank; 
e. Dipastikan juga penyelesaian pembangunan proyek sesuai dengan jadwal yang diberikan oleh pengembang;

f. Tetap cermat terhadap segala klausul dan pasal per pasal yang ada dalam perjanjian, jangan sampaii konsumen dirugikan.

Disamping beberapa hal diatas juga harus dicermati terkait kondisi harga property nasional yang dipengaruhi oleh banyak factor di Indonesia.

Secara kaidah hukum yang berlaku system penjualan seperti ini tidak dilarang, dan juga malah diperkenankan pada ketentuan UU Rumah Susun. Sebagaimana yang tercantum dalam pasal 42 ayat 1 UU Rumah Susun yang disebutkan bahwa pelaku usaha property atau pengembang dapat melakukan pemasaran sebelum adanya rumah susun yang berdiri.

Ketentuan hukum yang memberikan kepastian hukum terkait penjualan dengan system seperti ini memang belum ada, maka dari itu kembali lahi kepada kontrak atau klausul yang sudah disepakati kedua belah pihak yang dituangkan dalam bentuk PPJB(Simamora, 1996). Terbentuknya PPJB terjadi karena kedua belah pihak menyatakan kehendak awal yang nantinya tetap melaksanakan jual beli dalam proses sesungguhnya (Hartanto, 2015). Dalam hal perjajian seperti ini hanya disebut sebagai perjanjian obligatoir dimana perikatan seperti ini hanya menyatakan kebendaan yakni unit rumah hanya berpindah tangan, namun belum sampai hmenyatakan sebagai hak milik (Fuady, 1999) Nantiya dibutuhkan perjanjian lain atau disebut sebagai (zakelijke overeenkomst) yang nantinya menjadi dasar penyerahan benda tersebut yang dapat memberikan akibat hukum menjadi hak milik.

Pada dasarnya sama terkait PPJB yang didalamnya hanya memuat tentang hak dan kewajiban pihak yang mengikatkan diir dalam perjanjian tersebut. Terkait peralihan hak akan PPJB bisanya disebut dengan AJB atau Akta Jual Beli. Maka dari itu ini yang menjadi alas an PPJB masih disebut dengan perjanjian obligatoir.

PPJB yang telah disepakati dimana pada faktanya terlihat sebagai klausula baku yang tidak dapat diganggu gugat ataupun diberikan negosiasi oleh calonn konsumen dirasa muncul adanya unsure paksaan dan atas dasar kebutuhan konsumen ini, Meskipun terlihat seperti itu namun jika ditelaah kembali terkait salah satu unsure PPJB dimana harus menjadikan hal tersebut sebagai klausula baku, maka pihak pengembang haruslah tetap memberikan pelayanan dan mengakomodir keinginan dari para konsumen dengan semaksimal mungkin. Hal seperti ini merupakan bentuk dari adanya fenomena penyalahgunaan keadaan atau disebut dengan 
misbruk van omstandigheden yakni hilangnya hak kebebasan dari pembelli atau konsumen dalam hal kesepakatan yang tertuang dalam kontrak baku tersebut (Kurniawan \& Parameswary, 2014)

Wirjono Prodjodikoro memberikan pendapat yakni sebuah kausa yang disebutkan dalam suatu perjanjnian adalah isi dan tujuan yang mengakibatkan persetujuan itu dibuat. (Wirjono P,2000) Salah satu contoh misalkan dalam penjualan property, penyerahan status kepemilikan property tersebut merupakan kewajiban pengembang propoerti dan yang memiliki kewajiban melakukan pembayaran yakni konsumen.

Kausa yang digunakan dalam suatu perjanjian haruslah yang berkaitan dengan tujuan daripada pembuatan perjanjian tersebut. Suatu sebab perjanjian harus menjadi salah satu syarat yang diperbolehkan hendaknya dipahami dalam kerangka prinsip dalam asas kebebasan berkontrak. Pada dasarnya nantinya para pihak memang mendapatkan kebebasan dalam menentukan isi daripada perjanjian. Sebab atau kausa yang menajdi salah satu factor dalam hal pembentukan perikatan meskipun memiliki kebebasan namun tetap dalam batasan yang masih mengandng kepatutan dan kewajaran dalam suatu perjanjian. Jika perikatan tersebut yang diingikan terkait yang dilarang oleh ketentuan perundang-undangan maka dengan sendirinya perikatan tersebut batal demi hukum. (Prodjodikoro, 2000)

Jadi dalam ketentuan membuat PPJB harusnya tidak bertentangan dengan hukum yang berlaku. Pengertian PPJB ini yakni suatu perjanjian jual beli yang dilakukan oleh para pihak yang obyek perjanjiannya adalah tanah dan bangunan diatasnya nantinya setelah kewajiban dan hak terpenuhi maka akan dilakukan pengalihan atas obyek tersebut. Jika suatu PPJB diadakan karena suatu sebab yang tidak dilarang oleh undang-undang maka perikatan PPJB tersebut sah di mata hukum. Hal ini juga sejalan dengan ketentuan pasal 1338 ayat 1 dimana semua perjanjian yang pembuatannya sah dimata hukum maka berlaku bagi Para Pihak sehingga menjadi undang-undanng bagi seluruh pihak yang terlibat dalam perjanjian tersebut.

PPJB merupakan sebuah contoh perwujudan dari asas kebebasan berkontrak, dimana esensi di dalam asas kebebasan berkontrak merupakan hak bagi para pihak dalam membuat perjanjian. Termasuk Perjanjian Pengikatan Jual Beli (PPJB). PPJB yang dibuat oleh kedua belah pihak dengan tanpa ada paksaan yang dilakukan di hadapan notaris merupakan perwujudan pengaplikasian asas kebebasan berkontrak dalam PPJB.

Ruang lingkup asas kebebasan berkontrak menurut hukum perjanjian di Indonesia adalah : 
a. Memiliki suatu kebebasan dalam menyusun atau tidak suatu perikatan;

b. Kebebasan dalam memilih pihak dalam menyusun perikatan;

c. Kebebasan untuk menentukan seba atau kausa;

d. Dapat memiliki kebebasan dalam menentukan obyek perjanjian.

e. Kebebasan untuk menentukan bentuk suatu perjanjian;

f. Kebebasan menerima atau menyimpangi ketentuan Undang-Undang yang bersifat opsional (Rahman, 2003).

Perjanjian pengikatan jual beli dala Terkait perjanjian jual beli yang menggunakan strategi pre project selling yakni salah satu contoh perjanjian tertulis yang dibuat oleh pengembang yang memiliki kekuatan atau kedudukan yang lebih tinggi daripada perjanjian yang biasa dibuat. Pengertian perjanjian standar yakni perjanjian yang memiliki syarat dimana syarat tersebut ditentukan oleh salah satu pihak yang melakukan perikatan. Kedudukan perjanjian standar atau disebut juga dengan perikatan yang berbentuk baku yang sejatinya merupakan kebebasan individu sehingga pengusaha memiliki kebebasan dalam menentukan sikap bisnisnya.

Ketentuan klasusula baku dalam perikatan pre project selling yang dibuat oleh pengembang property suatu proyek membuat kedudukan konsumen menjadi tidak seimbang dan tidak sportif sehingga nantinya merugikan konsumen.

Pandnagan seperti ini bisa dibilang konsumen tidak memiliki pilihan untuk dapat melakukan negosiasi klausul tersebut. Konsumen dapat mengambil atau tidak melanjutkan proses perikatan(Muhammad, 1992) Yang kemudian menempatkan konsumen pada posisi yang sangat lemah. Ketentuan perjanjian standar yang memiliki isi kurang memberikan perlindungan terhadap konsumen. Nnatinya klausul tersebut berbentuk seperti formulir yang sudah menjadi ketentuan pihak pengembang yang isi dalam klausul tersebut sudah distandarisasi. Konsumen hanya akan mengisi kolom yang kosong seperti data diri dan nominal angsuran. Terdapat juga ketentuan diluar klausula baku yang dibuat oleh pengembang ada juga perjanjian terkait ganti rugi. Klausul ini menyebutkan pihak pengembang membayar ganti rugi secara menyeluruh akibat dari adanya perbuatan melawan hukum atau ingkar jani (wanprestasi), klausul tersebut disebut juga dengan perjanjian eksonerasi. (Miru, 2011)Ketentuan ini diatur dalam Pasal 18 UU No 8 tahun 1999 tentang Pencantuman Klausul Baku.Ketidak seimbangan pada pengikatan 
perjanjian pre project selling terkait syaratnya mengakibatkan ketidak seimbangan kedudukan antara pengembang dan konsumen.

Pandangan seperti ini terjadi karena terkait perjanjian pesan bangun ditentukan dan dibuat secara baku oleh pengusaha atau pengembang property yang kedudukannya lebih tinggi daipada calon konsumen. Bentuk perjanjian standar yang seperti ini dianggap sellau merugikan para konsumen, padahal bentuk perjanjian seperti ini lebih praktis.

Pada dasarnya dan faktanya perjanjian standar seringkali tidak memberikan perlindungan hak kepada konsumen. Pengusaha hanya mementingkan dirinya sendiri yang hanya berorientasi pada laba atau keuntungan. Model perjanjian seperti ini seringkali hanya menjadikan kewajiban konsumen menjadi prioritas yang harus segera dipenuhi, padahal konsumen juga memiliki hak-hak yang tidak sedikit. Kondisi seperti ini menjadikan ketidak seimbangan antara kedua belah pihak yang melakukan perikatan. Sanksi hukum yang tercantum dalam perikatan juga selalu memberikan ketidakseimbangan, seperti ganti rugi yang diberikan oleh pengembang akibat ingkar jani terkait progress pembangunan misalnya.

Rajeswari Kaniah dan Anwar Fazal yang dikutip oleh Yusuf Sofie menyebutkan dalam prakteknya klausula standar sringkali mencantumkan point pengecualian atau exemption clause. (Shofie, 2000) Salah satu contoh maksud dari pengecualian yakni tekait penyerahan unit bangunan yang sudah jadi kepada konsumen, kemudian apabila terdapat kelalaian oleh konsumen dalam hal pembayaran hingga mengakibatkan keterlambatan konsumen akan dibebankan denda atau pinalti. Kemudian pengembang dibebaskan terkait sanksi atau pinalti apabila melakukan penyerahan keterlambatan unit.

Pandangan Prof. Moch Isnaeni SH, MS dalam hal pre project selling dilihat dari sudut pandang ketentuan BW yang mejadi focus daripada bidang keilmuannya menilai BW awal mula dibentuk untuk tujuan memudahkan kegiatan bisnis yang semakin kompleks seiring dengan perkembangan zaman. Perjanjian Pre Project Selling merupakan salah satu bentuk perkembangan bisnis yang harusnya dapat di cover oleh ketentuan dalam BW.

Isu Pre Project Selling jika ditelaah dari sudut pandang undang-undang maka yang dipakai adalah BW dan UU No 5 tahun 1960 tentang Peraturan Pokok Dasar-Dasar Agraria. Ketika UUPA terbit maka akan mengesampingkan ketentuan hukum pada Buku II KUHPerdata yang mengatur tentang bumi, air, serta segala kekayaan yang terkadung didalamnya. Kemudian Prof Moch Isnaeni kemudian memberikan padangan yang lebih sempit terhadap aspek pengendalian pada asas kebebasan berkontrak pada system Pre Project Selling (Shofie, 2000). 
Dalam pembahasan isu ini Prof. Isnaeni mengekerucutkan pembahasannya pada aspek penendalian asas kebebasan berkontrak pada sistem pre project selling, menurut Porf. Isnaeni bahwa dalam Pasal 1338 BW tidak hanya terdapat prinsip kebebasan berkontrak, namun terdapat pula 17 prinsip yang menyertainya. Maka, melalui dasar tersebut muncullah PPJB yang dijadikan sebagai terobosan untuk mendapatkan pola sistem pre project selling. Dengan munculnya PPJB sebagai bagian dari pre project selling memberikan beberapa masalah, dikarenakan bentuk PPJB yang telah dibakukan sekiranya dalam hal ini tidak mungkin terbentuk perlindungan hukum intern, mengingat kedudukan konsumen relative lemah dengan daya tawar yang sangat rendah (Putra, 2017).

Dengan demikian, menurut penulis Pre Project Selling merupakan perjanjian yang tidak diatur secara pasti dalam ketentuan Buku III BW. Biasanya disebut juga perjanjian tidak bernama. Awal mula terbentuknya istilah Pre Project Selling didasari pada ketentuan pasal 1338 ayat $1 \mathrm{BW}$ yang biasa disebut Asas Kebebasan Berkontrak atau disebut juga Asas Pacta Sunt Servanda. Maka dari itu timbullah juga PPJB yang lebih mengakomodir alur dari pada pre project selling. Terkait adanya PPJB tidak serta merta menyelesaikan masalah dan tidak ada lubang permasalahan yang akan timbul, namun malah menjadikan PPJB tidak lagi memberikan perlindungan hukum pada konsumen yang membuat posisi konsumen memiliki daya tawar yang sangat rendah akan klausula baku dalam perjanjian pre project selling.

Kendati demikian pada fakta dilapangan terkait perjanjian pre project selling tidak ada payung hukum yang dapat memberikan kejelasan kepada masyarakat. Maka dari itu terdapat salah satu solusi penopang yakni adanya PPJB. Untuk itu agar pemerintah segera membuat regulasi yang dapat memberikan payung hukum terkait pre project selling di Indonesia. Hal ini dapat menjadi pedoman agar pelaku pembangunan dalam membuat perjanjian baku menghindari terjadinya klausula-klausula kabur dalam pemahaman yang seringkali menempatkan konsumen dalam posisi yang lemah. Oleh karena itu, sebelum perjanjian baku diedarkan kepada konsumen, maka perlu diadakan pengawasan klausula baku yang dilakukan oleh pihak ketiga. Dalam hal ini, pihak ketiga yang dapat dianggap memiliki wewenang untuk melakukan pengawasan tersebut ialah Pemerintah, maupun asosiasi-asosiasi pengembang properti. Konsumen diharapkan untuk selalu lebih waspada dalam membeli properti yang dipasarkan melalui sistem pre-project selling. Selain itu, konsumen diharapkan untuk memperhatikan klasula-klausula baku di dalam perjanjian yang ditetapkan oleh pelaku 
penegmbang. Melihat dari maraknya pelanggaran yang dilakukan oleh pelaku pembangunan dalam melakukan pemasaran dengan sistem pre-project selling serta tidak adanya sanksi yang diberikan oleh pelaku pembangunan atas pelanggaran pemasaran tersebut. Ketentuan yang perlu dilengkapi ialah pengaturan mengenai sanksi bagi pelaku pembangunan yang melakukan pemasaran dengan sistem pre-project selling yang tidak sesuai dengan ketentuan peraturan perundang-undangan.

\section{KESIMPULAN}

Pemasaran properti dengan sistem pre-project selling yang belum memiliki payung hukum membawa dampak bagi konsumen terkait belum adanya kepastian hukum mengenai status bangunan tersebut. Hal ini berarti bahwa peluang timbulnya wanprestasi yang dilakukan oleh pihak developer/pengembang membawa kerugian bagi konsumen yang sangat besar. Klausula baku yang menjadi pedoman terciptanya Perjanjian Pengikatan Jual Beli memang berawal dari adanya Asas Kebebasan Berkontrak. Menurut Hukum Perdata yang berlaku di Indonesia, kebebasan berkontrak dapat disimpulkan dari ketentuan pasal 1338 ayat (1) KUH Perdata, yang menyatakan bahwa semua kontrak (perjanjian) yang dibuat secara sah berlaku sebagai undang-undang bagi mereka yang membuatnya. Sumber dari kebebasan berkontrak adalah kebebasan individu sehingga yang merupakan titik tolaknya adalah kepentingan individu pula. Dengan demikian dapat dipahami bahwa kebebasan individu memberikan kepadanya kebebasan untuk berkontrak. Namun pada prakteknya Asas Kebebasan Berkontrak dalam PPJB malah disalahgunakan oleh Pihak Pengembang/Developer properti agar konsumen tidak diberikan pilihan untuk menambahkan atau mengubah tentang isi daripada kotrak PPJB.

Untuk mengatisipasi hal diatas, pemerintah perlu menyusun payung hukum sebagai perlindungan yang jelas bagi konsumen. Sehingga konsumen tidak ragu dan takut dalam memilih pihak pengembang atau developer dan dapat leih waspada terutama memperhatikan kalusula perjanjian yang ditandatangai. Selain itu, Pelaku pembangunan dalam membuat perjanjian baku lebih diharapkan untuk mempertimbangkan posisi konsumen agar menghindari terjadinya klausula-klausula kabur dalam pemahaman yang seringkali menempatkan konsumen dalam posisi yang lemah. Untuk meminimalisir pelanggaran yang merugikan masyarakat sebagai konsumen, maka paying hukum yang disusun pemerintah harus mengatur mengenai sanksi yang tegas bagi pelaku pembangunan yang melakukan pemasaran dengan sistem preproject selling yang tidak sesuai dengan ketentuan peraturan perundang-undangan. 


\section{REFERENCES}

Christie, S. (2012). Aspek Hukum Perjanjian Pengikatan Jual Beli Sebagai Tahapan Jual Beli Hak Atas Tanah Secara Angsuran. Jakarta: Universitas Indonesia.

Diantha, I. M. P. (2016). Metodologi Penelitian Hukum Normatif dalam Justifikasi Teori Hukum. Jakarta: Prenada Media Group.

Fuady, M. (2001). Hukum Kontrak (Dari Sudut Pandang Hukum Bisnis). Citra Aditya Bakti.

Hartanto, J. A. (2015). Karakteristik Hak Milik Atas Satuan Rumah Susun Dan Peralihannya Melalui Jual Beli. Surabaya: Universitas Airlangga.

Hernoko, A. Y. (2016). Asas Proporsionalitas Sebagai Landasan Pertukaran Hak dan Kewajiban Para Pihak Dalam Kontrak Komersial. Dalam Jurnal Hukum Dan Peradilan. https://doi.org/10.25216/jhp.5.3.2016.447-466

Hosiana, D. . (2019). Adakah Akibat Hukum dari Perjanjian Back Date ? Retrieved March 16, 2020, from https://www.hukumonline.com/klinik/detail/ulasan/lt5d53ce2ab2767/adakahakibat-hukum-dari-perjanjian-iback-date-i/

Kurniawan, F., \& Parameswary, A. (2014). KONSTRUKSI HUKUM PERLINDUNGAN ADHERED PARTY DALAM KONTRAK ADHESI YANG DIGUNAKAN DALAM TRANSAKSI BISNIS. Perspektif. https://doi.org/10.30742/perspektif.v19i3.17

Mardan, S. (2015). Asas Kebebasan Berkontrak dalam Hukum Perjanjian di Indonesia. Retrieved from https://www.kompasiana.com/suwandymardan/55001bbaa33311d37250fc23/asaskebebasan-berkontrak-dalam-hukum-perjanjian-di-indonesia

Miru, A. (2011). hukum perlidungan konsumen. Jakarta: PT. Raja Grafindo Persada.

Muhammad, A. (1992). Perjanjian Baku Dalam Praktek Perusahaan Perdagangan. Bandung: PT. Citra Aditya Bakti.

Nizam, A. (2017). HUKUM PERJANJIAN (KONTRAK) DAN ASPEK-ASPEKNYA. Retrieved March 16, 2020, from wordpress website: https://achmadnizamlaw.wordpress.com/category/hukum-perjanjian-kontrak-dan-aspekaspeknya/

Prodjodikoro, W. (2000). Azas-Azas Hukum Perjanjian. Mandar Maju.

Purbandari. (2013). Kepastian Dan Perlindungan Hukum Pada Pemasaran Properti Dengan Sistem Pre Project Selling. Majalah Ilmiah Widya.

Putra, E. K. (2017). PENGENDALIAN ASAS KEBEBASAN BERKONTRAK DALAM SISTEM PRE PROJECT SELLING. Retrieved March 16, 2020, from https://mkn.fh.unair.ac.id/pengendalian-asas-kebebasan-berkontrak-dalam-sistem-preproject-selling/?lang=id

Rabin, E. H. (1984). Revolution in Residential Lanlord-Tenant Law: Causes and Consequences. Cornell Law Review, 69, 531.

Rahman, H. (2003). Seri Keterampilan Merancang Kontrak Bisnis Contract Drafting. 
Bandung: PT. Citra Aditya Bakti.

Ridwan, A. S. Y., \& Rusdiana, S. (2018). KEBEBASAN MEMILIH PIHAK DALAM KONTRAK PADA ASAS KEBEBASAN BERKONTRAK DALAM SEWA MENYEWA KAMAR TINGGAL. Jurnal Hukum Ius Quia Iustum. https://doi.org/10.20885/iustum.vol25.iss1.art6

Satrio, J. (1995). Hukum Perikatan Yang Lahir Dari Perjanjian. Bandung: Citra Aditya Bakti.

Shofie, Y. (2000). Perlindungan Konsumen Dan Instrument-Instrumen Hukumnya. Bandung: PT. Citra Aditya Bakti.

Simamora, Y. S. (1996). Penerapan Prinsip Caveat Vendor Sebagai Sarana Perlindungan Bagi Konsumen Perumahan Di Indonesia. Surabaya: Universitas Airlangga.

Sjahdini, S. R. (2009). Kebebasan Berkontrak dan Perlindungan yang Seimbang Bagi Para Pihak Dalam Perjanjian Kredit Bank di Indonesia. Jakarta: Pustaka Utama Grafiti. 